\title{
Effect of Soil Amendments on Reclamation of Saline-Sodic Soil
}

\author{
K. Prapagar ${ }^{*}$, S.P. Indraratne ${ }^{1}$ and P. Premanandharajah ${ }^{2}$ \\ Postgraduate Institute of Agriculture \\ University of Peradeniya \\ Sri Lanka
}

\begin{abstract}
A pot experiment was conducted on saline-sodic soil to compare and assess the reclamation ability of different amendments and amendment combinations based on soil quality parameters. Treatments prepared were; T1-control (soil only), T2-soil + 1\% cow dung (CD), T3-soil + 1\% partially burnt paddy husk (PH), T4-soil + gypsum (GYP) $(100 \%$ Gypsum Requirement (GR), T5-soil + 1\% CD + GYP (100\% GR), T6-soil + 1\% PH + GYP (100\% GR). Organic amendments were applied at 1\% of soil weight, and gypsum was applied at $100 \%$ gypsum requirement as surface application and incubated at room temperature $\left(31 \pm 1{ }^{\circ} \mathrm{C}\right)$ for 90 days. After incubation, 42 days leaching was provided at a rate of $3 \mathrm{l} / \mathrm{pot}$ and the application was completed through 6 irrigation cycles/treatment with 7 days interval. After incubation and leaching of soils, onion variety Wallara-60 was grown in these pots. Results obtained both after the incubation and leaching show significant differences in bulk density, electrical conductivity (EC), $\mathrm{pH}$, exchangeable $\mathrm{Ca}^{2+}$ and Sodium Adsorption Ratio (SAR) among the treatments in comparison with the control. Among the treatments, the highest reduction in SAR $(14.62 \mathrm{mmol} / \mathrm{l})^{1 / 2}$ and $E C(1.71 \mathrm{dS} / \mathrm{m})$ were recorded by the GYP $+P H(T 6)$. A significant difference was observed in the tiller number among the treatments. Treatments GYP (T4), CD+GYP (T5) and PH+GYP (T6) showed a significantly higher yield than that of control, while T5 and T6 showing the highest yield. Therefore, incorporation of partially burnt paddy husk and cow dung increased the effectiveness of gypsum in reclaiming saline-sodic soils. Further, the onion yield parameters supported the findings.
\end{abstract}

Key words: Electrical conductivity, gypsum, leaching, Sodium Adsorption Ratio

\section{INTRODUCTION}

Saline and sodic soils are commonly occurring in most part of the world including Sri Lanka. Salinity problems have been reported in the dry and semi dry zone districts in the country namely Ampara, Batticcaloa, Hambantota, Moneragala, Polonnaruwa and Trincomalee (Kendaragama \& Bandara, 2000). In semi-arid zones soils tends to accumulate salts in the upper soil profile, especially when it is associated with an insufficient leaching or where soluble salts move upward in the soil profile. This kind of accumulation of salts in the soils may alter its physical and chemical properties, including soil structure and hydraulic conductivity. High exchangeable sodium and $\mathrm{pH}$ decrease soil permeability, available water

Department of Soil Science, Faculty of Agriculture, University of Peradeniya, Peradeniya, Sri Lanka

Department of Agricultural Chemistry, Eastern University, Sri Lanka

Author for correspondence: ckomathy14@yahoo.com 
capacity and infiltration rates through swelling and dispersion of clays as well as slaking of soil aggregates (Läuchli \& Epstein, 1990). These modifications may reduce the yield of crops growing on such soils.

The total global area of salt-affected soils including saline and sodic soils was $831 \mathrm{M}$ ha (Martinez-Beltran \& Manzur, 2005). The land degradation due to salinity is about 2\% $(47,000 \mathrm{ha})$ of the total agricultural land area in Sri Lanka (FAO, 1994). Saline-Alkali soils (Natraqualfs or Solodized Solonetz) are common in the drier regions of the lower coastal plain of the country where soils have developed on marine sediments (Panabokke, 1977). Boje Klein (1986) stated that $0.1 \mathrm{M}$ ha lands are affected by sodicity in Sri Lanka. Jeganathan and Adam (1982) reported that salinity and sodicity conditions do occur on Grumusols of Murunkan area. The leaching has been identified as the most effective method for removal of soluble salts from the rhizosphere in saline soils while application of chemical amendments to remove the sodium from the soil's cation exchange sites is necessary to reclaim sodic soils.

Saline-sodic soils can be made to yield a good crop through proper management practices. In this respect, the development of the most suitable reclamation technology or a combination of technologies important to optimize farm management and better crop yields in a salinesodic soil. Gypsum (GYP) is the most commonly used amendment due to its availability at low cost. Joachim et al. (2007) attributed the beneficial effect of combined use of farm yard manure (FYM) and GYP on the reclamation of sodic soils. The incorporation of rice husk significantly decreased soil EC, $\mathrm{pH}$ and SAR (Hussain et al., 1998). Addition of organic amendments to soils improves soil properties and it is highly accepted by the farmers. Against this backdrop, the present investigation was contemplated with the objectives of to evaluate the effectiveness of cow dung (CD) and partially burned paddy husk (PH) amended with GYP on reclaiming soil chemical and physical properties in a saline-sodic soil and to evaluate onion performance on these reclaimed soils.

\section{MATERIALS AND METHODS}

\section{Soil sampling and preparation}

Soil samples were collected randomly from $0-20 \mathrm{~cm}$ depth using a nursery spade, at identified saline-sodic sites in Sathurukkondan area along the coastal belt of the Batticaloa District. Collected soil samples were brought to the laboratory and spread on a polythene sheet and kept one day for air drying. In order to minimize soil heterogeneity, the samples were mixed thoroughly and sieved through $2 \mathrm{~mm}$ sieve. Salinity and sodicity indicator parameters, Electrical Conductivity (EC) and Sodium Adsorption Ratio (SAR) of the initial soil were measured in soil saturated paste extract and the values were $24.35 \mathrm{dS} / \mathrm{m}$ and 26.53 $(\mathrm{mmol} / \mathrm{l})^{1 / 2}$, respectively revealing that the soil of the experimental site is saline-sodic (Ghafoor et al., 2004).

\section{Amendments preparation and application}

$\mathrm{CD}$ and $\mathrm{PH}$ were chosen as organic amendments for this experiment. Organic amendments were ground to finer form and pass through a $2 \mathrm{~mm}$ sieve to ensure uniformity. Fifty grams of each were thoroughly mixed (at the ratio of $1 \%$ by the weight of soil) with $5 \mathrm{~kg}$ of sieved air dried soil and filled in plastic pots having the dimension of $23 \mathrm{~cm}$ diameter and $22 \mathrm{~cm}$ height. The samples were then mixed, compressed to a dry bulk density of $1.35 \mathrm{mg} / \mathrm{m}^{3}$. The 
agricultural grade GYP powder (90\% purity) was sieved to pass through a $2 \mathrm{~mm}$ sieve to ensure uniformity and high solubility. The calculated gypsum requirement (GR) was 1.22 $\mathrm{mg} / \mathrm{ha}$.

\section{Experimental design and treatments}

The study was arranged in a completely randomized block design using six treatments replicated four times. The pots containing $5 \mathrm{~kg}$ of air dried soil with different combinations of the amendments were prepared as follows: T1-Control (Soil), T2-Soil + 1\% CD, T3-Soil + $1 \%$ PH, T4-Soil + GYP (100\% GR), T5-Soil + 1\% CD + GYP (100\% GR), T6-Soil + 1\% PH + GYP $(100 \%$ GYP $)$.

These pots were stored at room temperature $\left(31 \pm 1{ }^{\circ} \mathrm{C}\right)$ for 90 days. The soil was equilibrated with the respective amendments at $50 \%$ soil water capacity and weights were maintained by the addition of water in weekly intervals during the period of incubation. After 90 days of incubation, the soil in each bucket was leached for 42 days. Leaching requirement was calculated from the leaching requirement equation and the amount required for leaching was $18.155 \mathrm{l} /$ bucket. Before the leaching, the pots were saturated first by keeping them in the water filled aluminum trays until soil surface become wet. Three liters of water was applied to each pot and the application was completed through 6 irrigation cycles per treatment with 7 days interval. At the end of the leaching, onion crop was grown in each pot under the greenhouse condition.

\section{Soil analysis}

Experiments were carried out in the laboratory of the Department of Agricultural Chemistry, Eastern University of Sri Lanka. Samples were prepared by passing through a $2 \mathrm{~mm}$ sieve after breaking the larger clogs using a wooden mallet. Particle size distribution was determined using Bouyocous Hydrometer method (Trout et al., 1987). The soil bulk density was determined using core method (Blake \& Hertge, 1986). EC and $\mathrm{pH}$ of soil-saturated paste were determined and SAR of the soil was also computed according to the following equation SAR $=\mathrm{Na}^{+} /\left[\mathrm{Ca}^{2+}+\mathrm{Mg}^{2+} / 2\right]^{1 / 2}$ (US Salinity Laboratory Staff, 1954). Sodium of soil saturation extract was determined using PFP-7 flame photometer (Thomas, 1982). $\mathrm{Ca}^{2+}+\mathrm{Mg}^{2+}$ cations were determined by titrating the saturation extract against $0.01 \mathrm{~N}$ EDTA solution to blue end point using $\mathrm{NH}_{4} \mathrm{Cl}+\mathrm{NH}_{4} \mathrm{OH}$ buffer and "Eriochome Black T" as an indicator (US Salinity Laboratory Staff, 1954).

\section{Crop analysis}

Since onion is classified as a salt-sensitive crop (Chang \& Randle, 2004), onion variety Wallara-60 was used for this experiment. Initially 5 bulbs were planted at the spacing of $6 \mathrm{x}$ $6 \mathrm{~cm}$ in each pot and after emergence 3 bulbs were maintained. All the agronomic practices were done according to the Department of Agriculture recommendation. After 45 days of planting, yield and tillers of onion was recorded.

\section{Data analysis}

Data collected was subjected to analysis of variance (ANOVA) using the general linear model (SAS, 1998). The mean separation was performed using the least significant difference (LSD) at $\mathrm{P}<0.05$. 


\section{RESULTS AND DISCUSSION}

Soil characterization was done before the start of the experiment. Results of physiochemical analysis of soils are shown in Table 1.

Table 1. Physiochemical characteristics of the experimental soil

\begin{tabular}{ll}
\hline Parameter & Value \\
\hline Bulk density $\left(\mathrm{Mg} / \mathrm{m}^{3}\right)$ & 1.35 \\
Texture & Sandy clay loam \\
$\mathrm{pH}$ & 7.86 \\
$\mathrm{EC}(\mathrm{dS} / \mathrm{m})$ & 24.35 \\
Exchangeable Ca & $2+(\mathrm{cmol} / \mathrm{kg})$ \\
SAR $\left((\mathrm{mmol} / \mathrm{l})^{1 / 2}\right)$ & 7.11 \\
\hline
\end{tabular}

Soil analysis results showed EC, and SAR values exceed maximum values for a normal arable soil $\left(4 \mathrm{dS} / \mathrm{m}\right.$ and $13(\mathrm{mmol} / \mathrm{l})^{1 / 2}$, respectively of EC and SAR), while the other parameters reported as bulk density of $1.35 \mathrm{Mg} / \mathrm{m}^{3}, \mathrm{pH}$ of 7.86 and exchangeable $\mathrm{Ca}^{2+}$ of $7.11 \mathrm{cmol} / \mathrm{kg}$ (Table 1). Soil properties such as EC and SAR clearly indicate that the study soil is fallen into the saline-sodic category (Ghafoor et al., 2004).

The effect of various amendments and their combination on soils after the leaching of soils for 42 days followed by 90 days of incubation is shown in Table 2 .

Table 2. Mean value of soil parameters after 42 days of leaching followed by 90 days of incubation

\begin{tabular}{|c|c|c|c|c|c|}
\hline Treatment & $\begin{array}{c}\text { BD } \\
\left(\mathbf{M g} / \mathrm{m}^{3}\right)\end{array}$ & $\begin{array}{c}\text { pH } \\
(1: 5)\end{array}$ & $\begin{array}{l}\text { ECe } \\
\text { dS/m }\end{array}$ & $\begin{array}{c}{\mathrm{Ex} . \mathrm{Ca}^{2+}} \\
(\mathrm{cmol} / \mathrm{kg})\end{array}$ & $\begin{array}{c}\text { SAR } \\
(\mathrm{mmol} / \mathrm{l})^{1 / 2}\end{array}$ \\
\hline T1- Control & $1.35^{\mathrm{a}}$ & $7.61^{\mathrm{a}}$ & $3.24^{\mathrm{a}}$ & $7.41^{\mathrm{f}}$ & $25.04^{\mathrm{a}}$ \\
\hline T2- CD & $1.29^{\mathrm{b}}$ & $7.54^{\mathrm{b}}$ & $2.79^{b}$ & $7.85^{\mathrm{e}}$ & $23.10^{\mathrm{b}}$ \\
\hline T3-PH & $1.26^{\mathrm{b}}$ & $7.49^{\mathbf{b}}$ & $2.70^{c}$ & $7.93^{d}$ & $22.12^{\mathrm{c}}$ \\
\hline T4-GYP & $1.30^{\mathbf{b}}$ & $7.31^{\mathrm{c}}$ & $2.34^{\mathrm{d}}$ & $9.06^{\mathrm{c}}$ & $17.19^{d}$ \\
\hline T5-GYP+CD & $1.27^{\mathrm{b}}$ & $7.24^{\mathrm{d}}$ & $1.98^{\mathrm{e}}$ & $9.68^{b}$ & $15.93^{e}$ \\
\hline T6-GYP+PH & $1.20^{\mathrm{c}}$ & $7.12^{\mathrm{e}}$ & $1.71^{\mathrm{f}}$ & $10.19^{\mathrm{a}}$ & $14.62^{\mathrm{f}}$ \\
\hline
\end{tabular}

Within columns, values followed by same letter(s) are not significantly different at $P=$ $0.05, * P<0.05$; n.s., not significant $(\mathrm{CD}=$ cow dung; $\mathrm{PH}=$ partially burnt paddy husk; $\mathrm{GYP}=$ gypsum; $\mathrm{BD}=$ bulk density; $\mathrm{SAR}=$ sodium adsorption ratio).

\section{Effect of amendments on soil bulk density}

Data showed that soil bulk density generally decreased after the application of amendments and leaching in comparison with the T1 although treatments T2, T3, T4 and T5 had no significant differences among themselves (Table 2). Continued supply of $\mathrm{Ca}^{2+}$ through dissolution of gypsum and binding effect of the soil particles together by organic amendments might have improved soil structure and aggregation, which would have been the reason for decrease in bulk density in the treatments. The best treatment for bulk density reduction was the T6. Calcium accumulations on the exchange sites have improved soil 
aggregation thus reducing the bulk density. In a field trial, Panchaban and Ta-oun (2002) found cow manure improved soil physical property while rice husk making soil pores larger.

\section{Effect of amendments on soil pH}

The $\mathrm{pH}$ reduced to 7.31 for GYP, 7.24 for GYP+CD combination and 7.12 for GYP+PH combination after leaching with water (Table 2). Differences between treatments to control were significant. Lowest value recorded for GYP $+\mathrm{PH}$ combination followed by GYP $+\mathrm{CD}$ and GYP treated soil. This might be due to water promoted gypsum dissolution, expediting the reclamation reactions and due to improvement of soil (Haq et al., 2001). Organic amendments only treatments showed a slight decrease in the $\mathrm{pH}$ in the range of 7.54 for $\mathrm{CD}$, and 7.49 for $\mathrm{PH}$ in comparison to the control. This may due to acidifying effect of organic acids produced during the course of decomposition of organic amendments. Guidi and Hall (1984) observed that the application of various organic materials decreased the $\mathrm{pH}$ values due to organic and inorganic acids formed when organic matter decomposition takes place.

\section{Effect of amendments on soil electrical conductivity (EC)}

Effect of GYP application with or without organic manures on EC is shown in Table 2. Among the treatments, GYP+PH combination was more effective in reducing the $\mathrm{EC}$ of the soil as compared to GYP or GYP $+\mathrm{CD}$ combination. The possible reason may be the improvement in porosity and hydraulic conductivity, which resulted in enhancing the leaching of salts. Udayasoorian et al. (2009) suggested that combined application of organic and inorganic ameliorants superior in reducing EC of soil. Sharma et al. (1982) reported decrease in $\mathrm{EC}$ as a result of gypsum application. Organic amendments only treatments (CD and $\mathrm{PH}$ ) also decreased $\mathrm{EC}$ and the numerical value of partially burnt paddy husk significantly lower than that of the control. The decrease in EC might be due to leaching followed by the addition of organic amendments, which produced organic acids during decomposition, which was responsible for leaching of salts. Rehman et al. (1996) achieved a substantially decreased EC of saline-sodic soils with the addition of different organic amendments. Decreased EC was the result of organic matter triggered leaching of excessive ions by improving the physical properties of soil.

\section{Effect of amendments on exchangeable calcium}

Table 2 shows the effect of different amendments on the exchangeable calcium of the investigated soil after leaching. Generally, exchangeable $\mathrm{Ca}^{2+}$ values were clearly increased due to any amendment applied after leaching. This may due to addition of organic amendments exchanging the adsorbed $\mathrm{Na}^{+}$for $\mathrm{Ca}^{2+}$ and in the displacement of $\mathrm{Na}^{+}$(Somani, 1990). High level of exchangeable $\mathrm{Ca}^{2+}$ was observed for GYP treated soils and combined application of GYP and organic amendments. Among them GYP+PH combination had the highest exchangeable $\mathrm{Ca}^{2+}$ content followed by GYP+CD combination and GYP treated soil. These treatments were significantly different among them and with the control.

\section{Effect of amendments on sodium adsorption ratio (SAR)}

A clear decrease in SAR was observed for amended soils after leaching. The decrease in SAR due to either increase in divalent cations $\left(\mathrm{Ca}^{2+}\right.$ and $\left.\mathrm{Mg}^{2+}\right)$, or decrease in monovalent cation $\left(\mathrm{Na}^{+}\right)$. The measured values of cations (Table 2) indicated that $\mathrm{Na}^{+}$decreased while $\mathrm{Ca}^{2+}$ increased in the exchangeable complex after the application of organic and inorganic amendments followed by leaching. The relatively high mobility and leachability of $\mathrm{Na}^{+}$from 
soil due to the applied amendments as compared with $\mathrm{Ca}^{2+}$, resulted in lower values of SAR, hence, the SAR values of the treated soil were sharply decreased with leaching. Effect of ameliorant and its combinations were significantly different at 5\% probability level. Gypsum only or combination with organic amendments proved superior to organic amendments only for treatments in reducing SAR. A decrease in SAR with simple leaching in control was likely due to mineral weathering and leaching out from the soil (Oster \& Shainberg, 1979). Chaudhary and Abaidullah (1988) reported that 100\% GYP applied for the GR was more effective in reducing the $\mathrm{SAR}$ than an equivalent amount of $\mathrm{CaCl}_{2}$.

\section{Plant growth}

Plant is a sensitive indicator of the efficiency of reclamation. Soil salinity threshold limit (EC $\mathrm{dS} / \mathrm{m}$ ) for onion for $50 \%$ yield reduction is 4.3 (Ayers \& Westcot, 1985). The influence of leaching and soil amendments added to a saline-sodic soil on yield and yield components of onion plants is presented in Table 3 .

\section{Table 3. Mean values of bulb weight and numbers of tillers of onion}

\begin{tabular}{lcc}
\hline Treatment & Number of tillers/pot & Weight of bulbs/pot (g) \\
\hline T1- Control & $11.7^{\mathbf{a}}$ & $17.58^{\mathbf{c}}$ \\
T2-CD & $12.7^{\mathbf{a}}$ & $20.14^{\mathbf{b c}}$ \\
T3-PH & $13.2^{\mathbf{a}}$ & $19.18^{\mathbf{b c}}$ \\
T4-GYP & $13.7^{\mathbf{a}}$ & $24.35^{\mathbf{b a}}$ \\
T5-GYP+CD & $14.7^{\mathbf{a}}$ & $26.89^{\mathbf{a}}$ \\
T6-GYP+PH & $14.5^{\mathbf{a}}$ & $26.30^{\mathbf{a}}$ \\
\hline
\end{tabular}

Within columns, values followed by same letter(s) are not significantly different at $P=0.05$; $(\mathrm{CD}=$ cow dung; $\mathrm{PH}=$ partially burnt paddy husk; $\mathrm{GYP}=$ gypsum $)$.

Tillering is an important characteristic of onion. There were differences in tiller numbers observed for all treatments. However, differences were non-significant among treatments and also with control. Among the practices, higher tillers were found in GYP $+C D$ treatment than of other treatments.

As shown in Table 3, the bulb yield significantly increased with all soil treatments over the control. The highest yield was found in GYP+CD treatment $(26.89 \mathrm{~g})$ followed by GYP $+\mathrm{PH}$ $(26.3 \mathrm{~g})$. However, differences were non-significant between them but significant with the control. These results suggest that combined amendments were superior to either one alone in their effect on increasing onion yield. It is possible that the observed changes in physical and chemical soil properties evidenced by decrease in electrical conductivity $(\mathrm{EC}<4 \mathrm{dS} / \mathrm{m}$ ) and SAR due to addition of CD, PH and GYP (Table 2) were responsible for increased onion yields.

Gypsum stone lining successfully reclaimed saline-sodic soils and improved crop yields at much low costs (Oster, 1994). Grewel (1984) found that gypsum and FYM in improving soil health and hence good plant growth. Gypsum along with FYM helped to improve P uptake by counteracting the nutrient imbalances within the plants (Izhar-ul-Haq et al., 2007). Similar results were also reported by Sharma et al. (1986). 
The treatments only with organic amendments also increased bulb weight, and the values were higher than the control but lower than the combinations of gypsum and organic amendments. Organic manuring has been found effective in increasing the crop yield and good physical health of soil. The organic amendments could provide plant growth influencing materials such as auxin, amino acids and vitamins which will be released to the soil following decaying (Melo \& De-Oliveira, 1999).

\section{CONCLUSIONS}

The study revealed that addition of gypsum and organic amendments (CD, PH) acted as ameliorant to saline-sodic soils. In this study, individual or combined effect of gypsum and simple leaching was more effective in changing EC and SAR. Gypsum application in combination with organic amendments improved the soil chemical properties by reducing the $\mathrm{EC}, \mathrm{SAR}$ and $\mathrm{pH}$, than the applying gypsum alone. Among the treatments GYP+PH had a remarkable effect in reducing soil salinity/sodicity. The yield of onion from GYP+CD treatment was higher compared with other treatments.

\section{ACKNOWLEDGMENT}

The research has been undertaken with the financial support of Eastern University.

\section{REFERENCES}

Ayers, R.S. and Westcot, D.W. (1985). Water quality for irrigation. FAO Irrig. and Drain. pp. 29.

Blake, G.R. and Hertge, K.H. (1986). Bulk density. In: Klute, A. (ed) Methods of soil analysis $\left(2^{\text {nd }}\right.$ ed). Part 1: Physical and mineralogical methods. Monograph No.9, ASA, Madison, WI, USA. pp. 363-375.

Boje-Klein, G. (1986). Problem soils as potential areas for adverse soil tolerant rice varieties in South and Southeast Asia. Soils Department, International Rice Research Institute, Los Bafios, Philippines.

Chang, P.T. and Randle, W.M. (2004). Sodium chloride in nutrient solutions can affect onion growth and flavor development. Hort. Sci. 39, 1416-1420.

Chaudhary, M.R. and Abaidullah, Initials are missing (1988). Efficiency of reclaments in reclaiming saline sodic soil. Proc. $1^{\text {st }}$ natl. Con. Soil Science, held at Lahore, Pakistan, October 6-8, 1985.

FAO. (1994). Land degradation in south Asia: Its severity causes and effects upon the people. World Soil Resources Reports, FAO, Rome. pp. 108.

Ghafoor, A., Qadir, M. and Murtaza, G. (2004). Sources of salts, genesis and classification of salt affected soils. In: Salt Affected Soils. Principles of Management. Univ. Agric, Faisalabad. pp. 39-42. 
Grewel, A. (1984). Reclamation of saline-sodic soils and the possibility of utilizing saline waters for leaching and irrigation. Soil Sci. 86, 254-261.

Guidi, G. and Hall, J.E. (1984). Effect of sewage sludge on the physical and chemical properties of soils. J. Indian Soc. of Soil Sci. 29, 129-131.

Haq, I.U., Habib, U.R., Niazi, B.H. and Saleem, M. (2001). Effect of horizontal flushing on the reclamation of sodic soils and yield of fodder crops after gypsum application. Int. J. Agric. Biol. 3, 323-325.

Hussain, N., Hassan, G., Ghafoor, A. and Sarwar, G. (1998). Biomelioration of sandy clay loam saline-sodic soil. Proceed. $6^{\text {th }}$ Intl. Micro-Irrigation Cong. March 8-10, 1998, Florida, USA, 293-300.

Izhar-ul-Haq., Muhammad, B. and Iqba, F. (2007). Effect of gypsum and farmyard manure on soil properties and wheat crop irrigated with brackish water. Soil \& Environ. 26(2), 164171.

Jeganathan, N. and Pain, A. (1982). Studies on salinity and sodicity on the rice growing Grumusols of Murunkan. Trop. Agriculturist, 138, 117-124.

Joachim, H.J.R., Makoi, P. and Ndakidemi, A. (2007). Reclamation of sodic soils in northern Tanzania, using locally available organic and inorganic resources. African J. Biotech. 6(16), 1926-1931.

Kendaragama, K.M.A. and Bandara, T.M.J. (2000). Changes in land use pattern in paddy lands. In Rice congress. pp. 251.

Lauchli, A. and Epstein, E. (1990). Plant response to salinity and sodic conditions. In: Tanji, KK (ed.), Agricultural Salinity Assessment and Management. American Society of Civil Engineers, New York, Mann. Rep. Eng. Pract. 71, 113-137.

Martinez-Beltran, J. and Manzur, C.L. (2005). Overview of salinity problems in the world and FAO strategies to address the problem. Proc. Int. Salinity Forum. Riverside, Calif. April 2005, pp. 311-313.

Melo, J.P.L. and De-Oliveira, A.P. (1999). Garlic production as a function of different water levels and bovine manure in soil. Horticultura Grasileira. 17, 11-15.

Oster, J.D. (1994). Irrigation with poor quality water. Agri. Water Mgt. 25, 271-97.

Oster, J.D. and Shainberg. And missing the initials] (1979). Separating exchangeable cation hydrolysis and soil weathering as affected by exchangeable sodium. Soil Sci. Soc. of Am. J. $43,444-447$.

Panabokke, C.R. (1977). Rice soils of Sri Lanka. In. Soil and Rice. International Rice Research Institute, Philippines. pp 19-34.

Panchaban, S. and Ta-oun, M. (2002). Fertilizer management for tomatoes growing in saline soil of the Northeast Thailand. $17^{\text {th }}$ WCSS, 14-21 August 2002, Thailand. Symposium No, 34. Paper, 352. 
Rahman, H., Abdel, A., Dahab, M.H. and Mustsfa, M.A. (1996). Impact of soil amendments on intermittent evaporation, moisture distribution and salt redistribution in saline-sodic clay soil columns. Soil Sci. 161(11), 793-802.

Rhoades, J.D. (1996). Salinity: Electrical conductivity and total dissolved solids. In D.L. Sparks et al. (ed.) Methods of soil analysis. Part 3. Chemical methods. SSSA Book Ser. 5. SSSA, Madison, WI.

SAS Institute (1998). SAS/STAT User, Guide, Version 6.12 Edn., SAS Institute, Cary, NC, USA, Vol: 1 .

Sharma, D.P., Mchta, K.K. and Yadav, J.S.P. (1982). Effect of reclamation practices on soil properties and crop gowth on farmers fields. J. Indian Soc. of Soil Sci. 29: 356-360.

Sharma, B.M. and Yadav, J.S.P. (1986). Iron, manganese and phosphorus uptake and yield of rice in sodic soil amended with gypsum and farm yard manure. J. Indian Soc. of Soil Sci. $34,849-54$.

Somani, L.L. (1990). Alkali soils: Their reclamation and management. Divyajyoti Prakashan Publ., Jodhpur, India.

Thomas, G.W. (1982). Exchangeable cations. In A.L. Page et al (eds.) Methods of Soil Analysis. Part 2. $2^{\text {nd }}$ ed. ASA and SSSA Madison. WI. pp. 159-165.

Trout, T.J., Garcia-Castilas, I.G. and Hyart, W.E. (1987). Soil Water Engineering, Field and Laboratory Manual. M/S Eurasia, New Delhi, India.

Udayasooriyan, R.M., Paul, S., Jayabalakrishnan, R.M, and Parameswari, E. (2009). Performance of Sugarcane Varieties under organic Amendments with Poor Quality Irrigation Water. Australian J. Basic Appl. Sci. 3(3), 1674-1684.

U.S. Salinity Laboratory Staff . (1954). Diagnosis and improvement of saline and alkali soils. USDA Agric. Handb. 60. U.S. Gov. Print. Office, Washington, DC. 